\title{
RISK FACTOR DISTRIBUTION AND LONG-TERM OUTCOMES IN YOUNG PATIENTS UNDERGOING PERCUTANEOUS CORONARY INTERVENTION IN MACEDONIA
}

\author{
Biljana Zafirovska, Magdalena Otljanska, Danica Petkoska and Sasko Kedev \\ University Clinic of Cardiology, Faculty of Medicine, \\ University of St Cyril \& Methodius, Skopje, Macedonia
}

\begin{abstract}
SUMMARY - The aim was to assess coronary artery disease (CAD) risk factor distribution and long-term outcomes in young patients undergoing percutaneous coronary intervention (PCI) in Macedonia. A total of 12,361 PCI patients (from March 2011 to December 2017) were included in the study. Group 1 included 309 young patients aged $\leq 40$ as the main study group, comparing them to 12,052 older PCI patients (group 2) during the study period. We compared CAD risk factor distribution, clinical and procedure characteristics. Additionally, angiographic data, long-term major adverse cardiac and cerebrovascular events (MACCE) and mortality were analyzed in group 1 patients. Median age was $36 \pm 4$ years in group 1 and $62 \pm 11$ years in group 2 . Male patients predominated in both groups ( $88 \%$ vs.73\%). Positive family history for CAD, smoking and obesity was much more common in the young group $(\mathrm{p}<0.0001)$. ST segment elevation myocardial infarction (STEMI) primary PCI was also more frequent with $48 \%$ of PCI in the young group $(\mathrm{p}<0.0001)$. Multivessel CAD and chronic total occlusion interventions were more common in the older group ( $51 \%$ and $28 \%$, respectively; $\mathrm{p}<0.0001)$. Procedure duration $(31 \pm 0.4$ vs. $35 \pm 22 \mathrm{~min})$ and fluoroscopy time $(9 \pm 4$ vs. $9 \pm 12$ min) were similar in both groups. There was no difference in access site bleeding (4.8\% vs. $4.3 \%$ ). During the 3.5 -year median follow up, MACCE was present in $1.9 \%$ of young patients. In conclusion, positive family history for $\mathrm{CAD}$, obesity and smoking were the most common risk factors in the young PCI population. Young PCI patients usually had single vessel CAD with STEMI being more frequent as the cause for primary PCI. Long-term annual survival exceeded $99 \%$ in these patients with excellent prognosis after PCI.
\end{abstract}

Key words: Coronary artery disease; Risk factors; Percutaneous coronary intervention; ST elevation myocardial infarction

\section{Introduction}

Coronary artery disease (CAD) is one of the most common causes of morbidity and mortality in the world population. CAD is most common in the elderly population and rarely occurs in people under 40

Correspondence to: Biljana Zafirovska, $M D$, Interventional Cardiology Division, University Clinic of Cardiology, Faculty of Medicine, University of St Cyril \& Methodius, Mother Teresa, 17, 1000 Skopje, Macedonia

E-mail: bibi_zafir@yahoo.com

Received October 16, 2018, accepted December 13, 2018 years. However, recent studies have shown that ever more young people develop CAD at an early age, most commonly due to their unhealthy lifestyle, stress and development of metabolic syndrome ${ }^{1-4}$.

Other studies have reported that risk factor presence, $\mathrm{CAD}$ presentation and angiographic data differ in the young compared to the old population ${ }^{5}$. Identifying risk factors that are most common in young people with CAD and understanding the process of atherosclerosis causing significant $\mathrm{CAD}$ in this population can help in prevention and decreasing the number of young CAD patients. 
Furthermore, angiographic, clinical and risk factor evaluation of $\mathrm{CAD}$ in the young population can contribute to determination of future prognosis and life expectancy in these patients.

In this study, we aimed to assess cardiovascular risk factor distribution, clinical and procedure characteristics in patients less than 40 years of age undergoing percutaneous coronary intervention (PCI) and compare these data with those on PCI patients older than 40 years. Additionally, angiographic data, major adverse cardiac and cerebrovascular events (MACCE) and mortality were analyzed in the young group with median follow up of 3.5 years (41.4 months, 20-60 IQR).

\section{Materials and Methods}

\section{Patient population}

This was a retrospective single center study including 12,361 PCI patients over a 7-year period (March 2011 to December 2017) referred for PCI to a large volume tertiary referral center. The group of young $\mathrm{pa}^{-}$ tients aged $\leq 40$ was the main study group (group 1 ). This group was compared to the group of older PCI patients (group 2) during the same period. Patients with previous PCI and myocardial infarction (MI) were excluded from the study (53 in group 1 and 5319 in group 2), so as not to have any confounding factors on group comparison. All included patients had de novo diagnosis of CAD and first time PCI.

Almost all procedures (99\%) were performed by transradial access (TRA) and experienced transradial operators with $>500$ diagnostic TRA procedures and $>300 \mathrm{PCI}$ procedures per year.

\section{Procedure}

Radial artery puncture and cannulation was performed using counter puncture technique with a $20 \mathrm{G}$ plastic intravenous cannula and 0.025 inch mini guidewire of $45 \mathrm{~cm}$, followed by 5 Fr or 6 Fr hydrophilic introducer sheath (Terumo, Japan) placement. Spasmolytic cocktail (verapamil $5 \mathrm{mg}$ ) was given intra-arterially through the radial sheath.

Pre-procedural retrograde radial arteriography was performed in all patients to define the radial artery anatomy from mid forearm to ulnobrachial anastomosis and to delineate ulnar artery anatomy as well, thus generating the access roadmap ${ }^{6-10}$.
All patients were pretreated with a loading dose of aspirin and clopidogrel $600 \mathrm{mg}$. After TRA sheath insertion, an initial bolus of $100 \mathrm{IU} / \mathrm{kg}$ of unfractionated heparin was administered intravenously.

Post-procedure management: the sheath was removed immediately after the procedure, regardless of the level of anticoagulation, and a compressive dressing or TR band (Terumo, Japan) was applied to the wrist. In order to decrease the rate of radial artery occlusion, we applied patent hemostasis by using pulse oximetry to confirm hemoglobin oxygen saturation on the punctured radial artery (>90\%) after hemostasis had been obtained (during measurement, ulnar artery was compressed manually ${ }^{11}$. Compression was applied for approximately 3 -hour period with gradual deflation of the TR band after the $1^{\text {st }}$ hour.

\section{Definitions}

Procedure time was defined as the time from puncture until completion of the procedure. Vascular access site complications were defined as the occurrence of an aneurysm, fistula, hematoma, loss of radial pulse, or radial nerve injury.

Access hematoma was classified into five grades according to EASY score (grade I: local hematoma, superficial $<5 \mathrm{~cm}$; grade II: hematoma with moderate muscular infiltration; grade III: forearm hematoma and muscular infiltration, below the elbow; grade IV: hematoma and muscular infiltration extending above the elbow; and grade V: ischemic threat - compartment syndrome $)^{12}$.

\section{Statistical analysis}

Categorical variables were expressed as numbers and percentages, and continuous variables as mean \pm $\mathrm{SD}$, or median (interquartile range). Statistical analysis was performed with JMP 11.O for Windows (SAS Inc., Cary, NC, USA).

\section{Results}

We compared 309 young PCI patients (aged $\leq 40$ ) in group 1 and 12,052 PCI patients (aged $>40$ ) in group 2. Median age was $36 \pm 4$ and $62 \pm 11$ years in group 1 and 2, respectively. Male patients predominated in both groups (88\% and 73\%, respectively). Considering cardiovascular risk factor distribution, 
Table 1. Risk factor distribution in study population

\begin{tabular}{|l|l|l|l|}
\hline Clinical variable & $\begin{array}{l}\text { PCI patients aged }<40 \\
(\mathrm{~N}=309)\end{array}$ & $\begin{array}{l}\text { PCI patients aged }>40 \\
(\mathrm{~N}=12,052)\end{array}$ & p value \\
\hline Age $($ years $)$ & $36.7 \pm 3.7(18-40)$ & $62 \pm 11(41-93)$ & \\
\hline Male & $273(88 \%)$ & $8782(73 \%)$ & 0.0527 \\
\hline BMI $\left(\mathrm{kg} / \mathrm{m}^{2}\right)$ & $30(19-47)$ & $26(19-52)$ & $<0.0001$ \\
\hline CAD risk factors & & & \\
Hypertension & $103(33 \%)$ & $\mathbf{6 4 3 2}(53 \%)$ & $<0.0001$ \\
Diabetes mellitus & $31(10 \%)$ & $2560(21 \%)$ & $<0.0001$ \\
Dyslipidemia & $62(20 \%)$ & $3120(26 \%)$ & 0.1560 \\
Smoking & $\mathbf{2 0 9}(67 \%)$ & $2484(20 \%)$ & $<0.0001$ \\
Positive family history for CAD & $\mathbf{1 2 9 ( 2 1 \% )}$ & $788(6.5 \%)$ & $<0.0001$ \\
\hline
\end{tabular}

$\mathrm{PCI}=$ percutaneous coronary intervention; $\mathrm{BMI}=$ body mass index; $\mathrm{CAD}=$ coronary artery disease
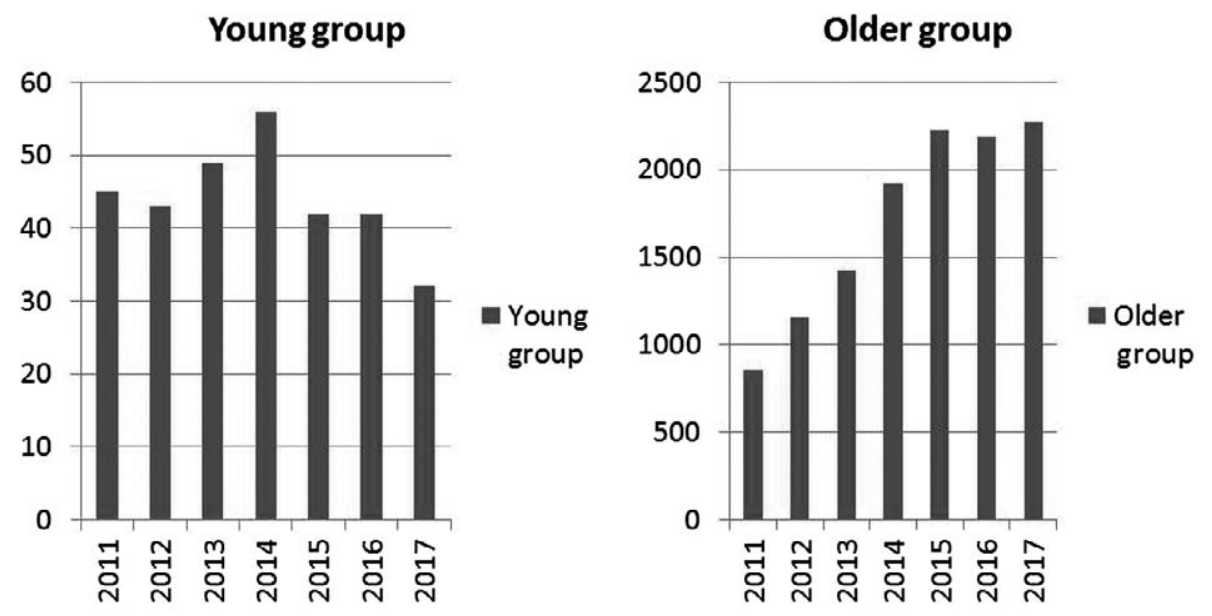

Fig. 1. Distribution of patients undergoing percutaneous coronary intervention according to years.

positive family history of CAD, smoking and obesity were much more common in the young group as compared with the older group $(\mathrm{p}<0.0001)$. On the other hand, hypertension and diabetes were much more frequent in the older group ( $53 \%$ vs. $33 \%$ and $21 \%$ vs. $10 \%$, respectively) (Table 1 ).

The group of young patients had primary PCI for ST segment elevation myocardial infarction (STEMI) more often than the older group (48\% vs. $35 \%$ of PCI interventions; $p<0.0001)$. Single vessel CAD was more common in the young group (63\%), whereas multivessel $\mathrm{CAD}$ and chronic total occlusion interventions were more common in the older group $(51 \%$ and $28 \%$, respectively; $\mathrm{p}<0.0001)$. The rate of PCI in the left main coronary branch (LMN) was similar in groups 1 and 2 (2.2\% vs. $2.9 \%$, respectively).

The number of young PCI patients was similar in all consecutive years analyzed in the study, with the lowest number recorded in 2017 ( $n=32)$, as opposed to the older PCI patients whose number increased over years from 857 in 2011 to 2269 patients in 2017 (Fig. 1).

Procedure duration ( $31 \pm 0.4$ vs. $35 \pm 22$ minutes), contrast volume $(120 \pm 33$ vs. $110 \pm 35 \mathrm{~mL})$ and fluoroscopy time ( $9 \pm 4$ vs. $9 \pm 12$ minutes) were similar in both groups. Ninety-nine percent of all interventions were performed by radial approach. In the young group, all PCI interventions were performed by wrist approach with 95\% radial access (TRA) and 5\% ulnar access 
Table 2. Procedural characteristics of study population

\begin{tabular}{|c|c|c|c|}
\hline \begin{tabular}{|l|} 
Procedural \\
variable \\
$(2011-2017)$ \\
\end{tabular} & $\mathrm{N}=309$ & $\mathrm{~N}=12,052$ & $p$ value \\
\hline $\begin{array}{l}\text { Procedure } \\
\text { PCI } \\
\text { PPCI }\end{array}$ & $\begin{array}{l}160(52 \%) \\
149(48 \%)\end{array}$ & $\begin{array}{l}7864(65 \%) \\
4188(35 \%)\end{array}$ & $\begin{array}{l}0.0520 \\
<0.0001\end{array}$ \\
\hline PCI in LM & $7(2.2 \%)$ & $358(2.9 \%)$ & 0.7250 \\
\hline CTO PCI & $30(10 \%)$ & $3502(28 \%)$ & $<0.0001$ \\
\hline $\begin{array}{l}\text { Single vessel } \\
\text { CAD }\end{array}$ & $228(63 \%)$ & $5886(49 \%)$ & $<0.0001$ \\
\hline $\begin{array}{l}\text { Multi vessel } \\
\text { CAD }\end{array}$ & $114(37 \%)$ & $6166(51 \%)$ & $<0.0001$ \\
\hline $\begin{array}{l}\text { Sheath size } \\
5 \mathrm{~F} \\
6 \mathrm{~F}\end{array}$ & $\begin{array}{l}32(10 \%) \\
277(90 \%)\end{array}$ & $\begin{array}{l}1050(8.7 \%) \\
11002(91.3 \%)\end{array}$ & $\begin{array}{l}0.6527 \\
0.6527\end{array}$ \\
\hline $\begin{array}{l}\text { Fluoroscopy } \\
\text { time (min) }\end{array}$ & $9(1-64)$ & $9(1-90)$ & 0.9643 \\
\hline $\begin{array}{l}\text { Procedural } \\
\text { time (min) }\end{array}$ & $31 \pm 0.4$ & $35 \pm 22$ & 0.0823 \\
\hline $\begin{array}{l}\text { Access site } \\
\text { bleeding } \\
\text { complications } \\
\text { Hematoma } \\
\text { grade } 4 / 5\end{array}$ & $\begin{array}{l}15(4.8 \%) \\
1(0.3 \%)\end{array}$ & $\begin{array}{l}523(4.3 \%) \\
29(0.24 \%)\end{array}$ & 0.9402 \\
\hline $\begin{array}{l}\text { Clinical RA } \\
\text { spasm }\end{array}$ & $9(2.9 \%)$ & $490(4.0 \%)$ & $<0.0001$ \\
\hline $\begin{array}{l}\text { Length of stay } \\
<2 \text { days }\end{array}$ & $123(40 \%)$ & $5290(44 \%)$ & 0.3420 \\
\hline $\begin{array}{l}\text { Same day } \\
\text { discharge }\end{array}$ & $20(6.4 \%)$ & $906(7.5 \%)$ & 0.6527 \\
\hline
\end{tabular}

$\mathrm{PCI}=$ percutaneous coronary intervention; $\mathrm{PPCI}=$ primary $\mathrm{PCI}$; $\mathrm{CTO}=$ chronic total occlusion; $\mathrm{CAD}=$ coronary artery disease; $\mathrm{LM}=$ left main; $\mathrm{RA}$ = radial artery

(TUA). In the older group, $99.8 \%$ of interventions were performed by wrist approach with $97.7 \%$ TRA and $2.1 \%$ TUA. Access site bleeding complications were similar in both groups (4.8\% vs. $4.3 \%)$, with radial artery spasm being higher in group 2 (4.0\% vs. $2.9 \%$; $<<0.0001)$. The length of hospital stay was similar in both groups ( $<2$ days in $40 \%$ and $44 \%$, respectively) (Table 2).

Angiographic data assessment was performed on all PCI interventions in group 1. Anterior STEMI with left anterior descendant artery (LAD) as culprit was most common presentation in the young STEMI group (48\%). Inferior MI with right coronary artery

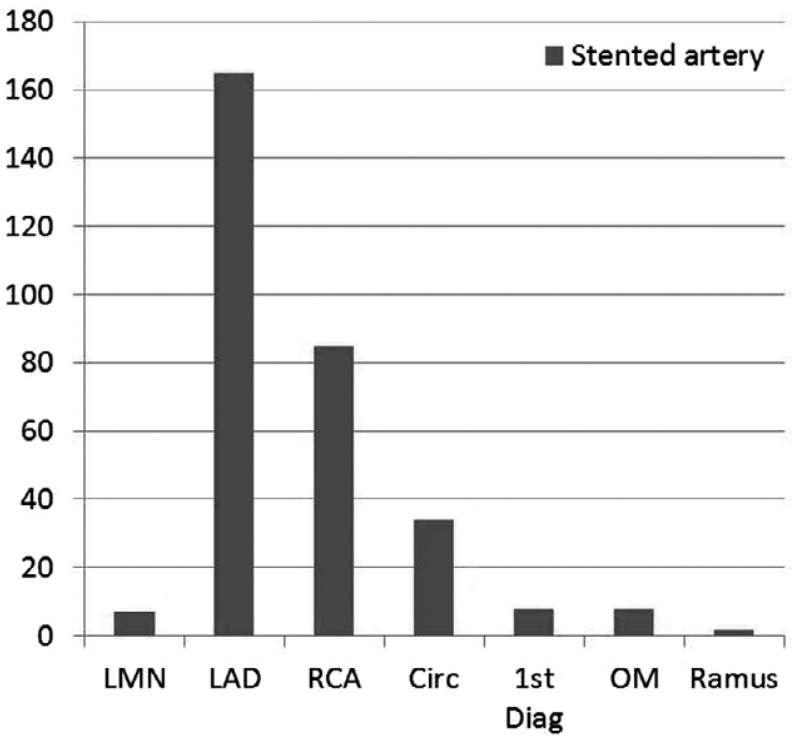

Fig. 2. Stented artery on primary intervention in young patients.

$\mathrm{LMN}=$ left main artery; LAD = left anterior descending artery; $\mathrm{RCA}=$ right coronary artery; $\mathrm{CIRC}=$ circumflex artery, $1^{\text {st }} \mathrm{OM}=$ obtuse marginal branch;, $1^{\text {st }}$ Diag = diagonal artery

Table 3. Long-term clinical follow up: MACCE and mortality in the group of young patients

\begin{tabular}{|l|l|}
\hline MACCE and mortality & $\mathrm{n}(\%)$ \\
\hline Myocardial infarction & $5(1.6)$ \\
Cerebrovascular insult & 0 \\
Target vessel revascularization & $8(2.5)$ \\
Death & $1(0.3)$ \\
Major vascular complications & $1(0.3)$ \\
Access site bleeding & $15(4.8)$ \\
complications & \\
Sign of hand ischemia & 0 \\
Median follow up & 41 months (44 IQR) \\
\hline
\end{tabular}

MACCE = major adverse cardiac and cerebrovascular events

(RCA) as culprit was present in 19\% of STEMI interventions.

In overall PCI interventions in the young group, first time PCI was most commonly performed on the LAD (53\%), followed by RCA (27\%) and circumflex artery (11\%) (Fig. 2).

During the 3.5-year median follow up (41 months, 20-40 IQR), MACCE was present in $1.9 \%$ of group 1 patients. Of these, $1.6 \%$ had MI and death rate was 
$0.3 \%$ in overall follow up. Only one patient with LMN disease died during hospital stay. Target vessel revascularization occurred in $2.5 \%$ of patients at final follow up (Table 3).

\section{Discussion}

In this study, we analyzed the characteristics of all young consecutive PCI patients aged $\leq 40$ treated during a 7-year period and compared these data with those on older PCI population in the same period. By comparing these two groups of PCI patients, we aimed to evaluate differences that could identify the risk factors for CAD in young patients in our country and help us improve CAD prevention in the young.

In the young population, CAD is becoming ever more common worldwide and published studies can help define the risk factors and prevent $\mathrm{CAD}^{1,2,5}$.

Studies involving this population are usually single center studies without enough data from prospective multicenter studies ${ }^{13,14}$. The advantage of our study was that it reflected real life data and clinical practice in the young PCI population in Macedonia over 7 years with long-term follow up.

Our results showed that the risk factor distribution in the young population of PCI patients consisted of positive family history, smoking and obesity that were much more common as compared with the older group population. Furthermore, first time presentation also differed considerably, with a greater number of STEMI presentations in almost half of the patients in the young group. Single vessel CAD was most common in this group, with LAD as the most common artery stented. The number of young PCI patients in our population was consistent over years, as opposed to the older PCI population whose number grew and reached highest figure in 2017. This was most probably due to the aging of the population and ever more elderly patients being referred for PCI as opposed to earlier years. Advances in PCI technology and techniques over the past decade had also led to improving outcomes and lowering complication rates in the otherwise complicated PCI patient group. Consistency in the number of younger PCI patients was comparable

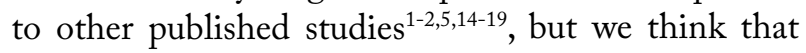
this value is underestimated due to the late detection of CAD in young patients with common multi-vessel disease in their early forties. A speedy cardiovascular diagnosis and treatment ${ }^{20}$ is necessary for early detection and treatment of young CAD patients. In addition, a good primary prevention program is needed to further decrease this number at the national level.

The survival rate in our young PCI population was 99.7\% at 3.5-year median clinical follow up, with excellent prognosis and low rate of MACCE. Our findings are similar to other previously published studies $^{5,15-19}$, but also present the first time published data from our country.

It is important to note that primary PCI strategy in STEMI is the default strategy in our country with $<1 \%$ of patients undergoing fibrinolysis during STEMI. Our hospital is a high volume transradial center ( $80 \%$ of all PCI interventions in the country) and the main referral center for primary PCI and complex procedures. Transradial approach has been the default approach in our center since $2008^{21}$, which is in accordance with the ESC guidelines for treatment of PCI patients $^{22-24}$, and most probably has contributed to the low MACCE and mortality in our results ${ }^{7-9}$.

Upon analyzing the risk factors in our young PCI population, we can conclude that eliminating smoking, which was present in $67 \%$ of the young PCI population as one of the causes of atherosclerosis, can help us significantly in decreasing CAD. We also found that the young PCI group had a medium body mass index 30 , indicating that obesity is also a significant risk factor for $\mathrm{CAD}$ in the young Macedonian population and that lifestyle modification can also help decrease the number of young CAD patients ${ }^{25}$. Early diagnosis and treatment with regular cardiologic check-ups and elimination of other risk factors are necessary for young patients with strong positive family history of $\mathrm{CAD}^{26}$.

\section{Study limitations}

This was a retrospective study and larger prospective multicenter studies are needed to prove our results. The study produced real life results on all PCI patients included over a 7-year period. We only excluded PCI patients that had previous $\mathrm{MI}$ and PCI, to have a more precise analysis of risk factor distribution and comparison between the two groups and to eliminate bias.

\section{Conclusion}

Positive family history of CAD, obesity and smoking were the most common risk factors in the young 
PCI population. Young PCI patients usually had single vessel CAD, with STEMI being more frequent as the cause for primary PCI. Long-term annual survival was more than $99 \%$ in these patients, with excellent prognosis after PCI. Working towards prevention and lifestyle modification can help reduce the number of young patients with CAD.

\section{References}

1. Wei-xian Yang, Zheng Yang, Yong-jian Wu, Shu-bin Qiao, Yue-jin Yang, Ji-lin Chen. Factors associated with coronary artery disease in young population (age $\leq 40$ ): analysis with 217 cases. Chin Med Sci J. 2014;29(1):38-42. doi: 10.1016/s10019294(14)60022-5

2. Aggarwal A, Aggarwal S, Sharma V. Cardiovascular risk factors in young patients with coronary artery disease: differences over a decade. J Cardiovasc Thorac Res. 2014;6:169-73. doi: 10.15171/jcvtr.2014.006

3. Rosengren A, Hawken S, Ounpuu S, Sliwa K, Zubaid M, Almahmeed WA, et al. Association of psychosocial risk factors with risk of acute myocardial infarction in 11,119 cases and 13,646 controls from 52 countries (the INTERHEART study): case-control study. Lancet. 2004;364:953-62. DOI: 10.1016/S0140-6736(04)17019-0

4. Rozanski A, Bairey C, Krantz D, Friedman J, Resser KJ, Morell $\mathrm{M}$, et al. Mental stress and the induction of silent myocardial ischemia in patients with coronary artery disease. $\mathrm{N} \mathrm{Engl} \mathrm{J} \mathrm{Med.}$ 1988;318:1005-12. doi: 10.1056/NEJM198804213181601

5. Waziri H, Jørgensen E, Kelbæk H, Stagmo M, Pedersen F, Lagerqvist B, et al. Short- and long-term survival after primary percutaneous coronary intervention in young patients with ST-elevation myocardial infarction. Int J Cardiol. 2016 Jan 15;203:697-701. doi: 10.1016/j.ijcard.2015.09.012

6. Zafirovska B, Petkoska D, Antov S, Vasilev I, Jovkovski A, Kalpak $\mathrm{O}$, et al. Radial artery anomalies in the Macedonian population during transradial angiography procedures. Sanamed. 2016 Jun;11(2):87-92. doi: 10.5937/sanamed1602087Z.

7. Kedev S, Zafirovska B, Kalpak O, Antov S, Kostov J, Spiroski I, et al. Macedonia: coronary and structural heart interventions from 2010 to 2015. EuroIntervention. 2017 May 15;13(Z): Z47-Z50. doi: 10.4244/EIJ-D-16-00827

8. Kedev S, Zafirovska B, Antov S, Kostov J, Spiroski I, Boshev M, et al. Total wrist access for angiography and interventions: procedural success and access site crossover in a high volume transradial center. Cardiovasc Revasc Med. 2018 Jul-Aug;19(5 Pt B):570-4. doi: 10.1016/j.carrev.2017.12.009

9. Zafirovska B, Antov S, Kostov J, Spiroski I, Vasilev I, Jovkovski $\mathrm{A}$, et al. Benefit of routine preprocedural radial artery angiography in STEMI patients. Catheter Cardiovasc Interv. 2019 Jan 1;93(1):25-31. https://doi.org/10.1002/ccd.27711

10. Ostojić Z, Bulum J, Ernst A, Strozzi M, Marić-Bešić K. Frequency of radial artery anatomic variations in patients under- going transradial heart catheterization. Acta Clin Croat. 2015 Mar;54(1):65-72.

11. Pancholy SB, Bernat I, Bertrand OF, Patel TM. Prevention of radial artery occlusion after transradial catheterization: the PROPHET-II randomized trial. JACC Cardiovasc Interv. 2016 Oct 10;9(19):1992-9. doi: 10.1016/j.jcin.2016.07.020

12. Bertrand OF, De Larochelliere R, Cabau JR, Proulx G, Gleeton O, Nguyen CM, et al. Predictors for Early Discharge After Transradial Stenting of Coronary Arteries (EASY) study investigators. A randomized study comparing same-day home discharge and abciximab bolus only to overnight hospitalization and abciximab bolus and infusion after transradial coronary stent implantation. Circulation. 2006;114:2636-43. doi: 10.1161/CIRCULATIONAHA.106.638627

13. Christus T, Shukkur AM, Rashdan I, Koshy T, Alanbaei M, Zubaid M, et al. Coronary artery disease in patients aged 35 or less - a different beast? Heart Views. 2011;12:7-11. doi: 10.4103/1995-705X.81550

14. Garoufalis S, Kouvaras G, Vitsias G, Perdikouris K, Markatou P, Hatzisavas J, et al. Comparison of angiographic findings, risk factors, and long term follow-up between young and old patients with a history of myocardial infarction. Int J Cardiol. $1998 \mathrm{Nov}$ 30;67(1):75-80. doi: 10.1016/s0167-5273(98)00194-6

15. Cole JH, Miller JI3 ${ }^{\text {rd }}$, Sperling LS, Weintraub WS. Long-term follow-up of coronary artery disease presenting in young adults. J Am Coll Cardiol. 2003;41:521-8.

16. Chua SK, Hung HF, Shyu KG, Cheng JJ, Chiu CZ, Chang $\mathrm{CM}$, et al. Acute ST elevation myocardial infarction in young patients: 15 years of experience in a single center. Clin Cardiol. 2010;33:140-8. doi: 10.1002/clc.20718

17. Puricel S, Lehner C, Oberhansli M, Rutz T, Togni M, Stadelmann $\mathrm{M}$, et al. Acute coronary syndrome in patients younger than 30 years - aetiologies, baseline characteristics and longterm clinical outcome. Swiss Med Wkly. 2013;143:w13816. doi: 10.4414/smw.2013.13816. eCollection 2013

18. Winter M, Blessberger H, Alimohammadi A, Pavo N, Huber $\mathrm{K}$, Wojta J, et al. Long-term outcome and risk assessment in premature acute myocardial infarction: a 10-year follow-up study. Int J Cardiol. 2017 Aug1;240:37-42. doi: 10.1016/j.ijcard.2017.03.146

19. Hirota Y, Sawano, M, Numasawa Y, Ueda I, Noma S, Suzuki $\mathrm{M}$, et al. Characteristics and in-hospital outcomes in young patients presenting with acute coronary syndrome treated by percutaneous coronary intervention. Cardiovasc Interv Ther. 2018;33:154. https://doi.org/10.1007/s12928-017-0471-z

20. Štambuk K, Pavlović N, Manola S, Krčmar T, Pintarić H, Delić-Brkljačić D. Wellens' syndrome in a female patient presenting to emergency room after resolving exercise-induced chest pain. Acta Clin Croat. 2010 Mar;49(1):73-6.

21. Kedev S, Kalpak O, Dharma S, Antov S, Kostov J, Pejkov H, et al. Complete transitioning to the radial approach for primary percutaneous coronary intervention: a real world single center registry of 1808 consecutive patients with acute ST elevation myocardial infarction. J Invasive Cardiol. 2014;26(9):475-82. 
22. Neumann F, Sousa-Uva M, Ahlsson A, Alfonso F, Banning AP, Benedetto U, et al. ESC Scientific Document Group; 2018 ESC/EACTS Guidelines on myocardial revascularization. Eur Heart J. 2019 Jan 7;40(2):87-165 https://doi.org/10.1093/eurheartj/ehy394

23. Ibanez B, James S, Agewall S, Antunes MJ, Bucciarelli-Ducci C, Bueno H, et al. 2017 ESC Guidelines for the management of acute myocardial infarction in patients presenting with STsegment elevation: the Task Force for the Management of Acute Myocardial Infarction in Patients Presenting with ST-Segment Elevation of the European Society of Cardiology (ESC). Eur Heart J. 2018 Jan;39(2):119-77. https://doi. org/10.1093/eurheartj/ehx393.

24. Roffi M, Patrono C, Collet JP, Mueller C, Valgimigli M, Andreotti F, et al.; 2015 ESC Guidelines for the management of acute coronary syndromes in patients presenting without persistent ST-segment elevation: Task Force for the Management of Acute Coronary Syndromes in Patients Presenting without Persistent ST-Segment Elevation of the European Society of Cardiology (ESC). Eur Heart J. 2016 Jan 14;37(3):267-315. doi: 10.1093/eurheartj/ehv320. Epub 2015 Aug 29

25. Christiansen MK, Jensen JM, Brøndberg AK, Bøtker HE, Jensen HK. Cardiovascular risk factor control is insufficient in young patients with coronary artery disease. Vasc Health Risk Manag. 2016;12:219-27. doi:10.2147/VHRM.S106436

26. Otaki Y, Gransar H, Berman D.S, Cheng VY, Dey D, Lin FY, et al. Impact of family history of coronary artery disease in young individuals (from the CONFIRM Registry). Am J Cardiol. 2013 Apr 15;111(8):1081-6. doi: 10.1016/j.amjcard.2012.12.042

Sažetak

\title{
DISTRIBUCIJA RIZIČNIH ČIMBENIKA I DUGOROČNI ISHODI U MLADIH BOLESNIKA PODVRGNUTIH PERKUTANOJ KORONARNOJ INTERVENCIJI U MAKEDONIJI
}

\author{
B. Zafirovska, M. Otljanska, D. Petkoska i S. Kedev
}

Cilj istraživanja bio je procijeniti distribuciju rizičnih čimbenika za koronarnu arterijsku bolest (KAB) i dugoročne ishode kod mladih bolesnika podvrgnutih perkutanoj koronarnoj intervenciji (PKI) u Makedoniji. U istraživanje je bilo uključeno ukupno 12.361 bolesnika podvrgnutih PKI (od ožujka 2011. do prosinca 2017. godine). Skupina 1. obuhvatila je 309 mladih bolesnika u dobi od $\leq 40$ godina kao glavna ispitna skupina koja je tijekom istraživanja uspoređena sa skupinom 2 . koja je uključivala 12.052 starijih bolesnika. Uspoređivali smo distribuciju rizičnih čimbenika za KAB te kliničke osobine i značajke zahvata. Uz to, u skupini 1. analizirani su angiografski podaci, dugoročni teži štetni srčani i cerebrovaskularni dogadaji (major adverse cardiac and cerebrovascular events, MACCE) i smrtnost. Medijan dobi bio je $36 \pm 4$ godine u skupini 1. i $62 \pm 11$ godine u skupini 2. Pozitivna obiteljska anamneza za KAB, pušenje i pretilost bili su znatno češći u mladoj skupini ( $<<0,0001)$. Primarna PKI zbog STEMI bila je također češća s 48\% PKI u mladoj skupini $(\mathrm{p}<0,0001)$. KAB višestrukih krvnih žila i intervencije zbog kronične potpune okluzije bile su češće u starijoj skupini ( $51 \%$ odnosno 28\%; $<<0,0001)$. Trajanje zahvata $(31 \pm 0,4$ prema $35 \pm 22 \mathrm{~min})$ i fluoroskopije $(9 \pm 4$ prema $9 \pm 12 \mathrm{~min})$ bilo je slično u objema skupinama. Nije bilo razlike u krvarenju na ulaznom mjestu (4,8\% prema 4,3\%). Tijekom medijana praćenja od 3,5 godine MACCE su zabilježeni u $1,9 \%$ mladih bolesnika. U zaključku, najčešći čimbenik rizika u populaciji mladih bolesnika podvrgnutih PKI bila je pozitivna obiteljska anamneza za KAB, pretilost i pušenje. Mladi bolesnici uglavnom su imali KAB jedne krvne žile i podvrgnuti su primarnoj PKI zbog STEMI. Dugoročno godišnje preživljenje bilo je više od $99 \%$ u ovih bolesnika s izvrsnom prognozom nakon PKI.

Ključne riječi: Koronarne arterije, bolesti; Rizični čimbenici; Perkutana koronarna intervencija; Infarkt miokarda s elevacijom ST-segmenta 